\title{
SELF-EFFICACY AMONG STUDENTS IN HIGHER EDUCATIONAL INSTITUTIONS DURING ONLINE LEARNING SELF-EFFICACY AMONG STUDENTS IN HIGHER EDUCATIONAL INSTITUTIONS DURING ONLINE LEARNING
}

\author{
Dora Levterova-Gadjalova ${ }^{1}$, Galin $^{\text {Tsokov }}{ }^{2}$
}

\begin{abstract}
Distance learning around the world has set new requirements for educational institutions and particularly for the students. Self-efficacy is one of the essential factors for success. Self-efficacy in an online learning environment is related to the confidence in one's ability to succeed, knowledge and ability to use the technology, and the casualness of success in the new education model, which is evolving rapidly from Education 2.0. to Education 4.0. A survey was conducted among 134 students from higher educational institutions (HEIs). The results of the study demonstrate that self-assessment, emotional responses, motivation for academic success, and self-referential information of students in HEIs regarding the learning content are unstable. A rise in the knowledge and usage of various electronic devices and electronic resources has been reported along with a rise in cognitive load. There is an effect of cognitive distortion on mastering the learning content and setting more challenging goals in terms of the transition from the traditional model of learning to distance learning and on their learning competencies .
\end{abstract}

UDC Classification: 378, DOI: https://doi.org/10.12955/pss.v2.226

Keywords: Self-efficacy, online learning, students, HEIs.

\section{Introduction}

The effectiveness of online learning is discussed mainly through the prism of technological support, learning design, methods and styles of teaching in an electronic environment, and students' academic success in higher education institutions (HEIs). Relatively fewer studies are found on the self-efficacy of students in HEIs and the dynamics of their learnings on Education 2.0, based on active interactions and communications to Education 3.0, based on the semantic filling of the Web and to Education 4.0., based on a mobile environment. The World Wide Web, Web 2.0, Web 3.0, and Web 4.0 technologies offer exceptional learning opportunities by connecting people via networks, ideas, and content. Today, "it is more important to know where to find information than to have it. Know-how and know-what have been replaced by know-where - to know where to find the necessary knowledge" (Siemens, 2005). A critical component in the online learning for students from HEIs is their self-efficacy. When the self-efficacy among students from HEIs students in online learning is high, they tend to have higher learning goals and are more committed to master the learning content.

This article focuses on the perceived self-efficacy of students from HEIs during online learning.

The following research questions were asked:

- What is the overall perceived self-efficacy of students in HEIs?;

- What is the self-assessment of their digital competence?;

- What is the perceived self-efficacy of students in HEIs in an online learning environment based on their self-assessment of $4 \mathrm{Cs}$ (critical thinking, communication, cooperation and creativity) and cognitive load.

\section{Theoretical Framework}

Forced by the pandemic, learning in an electronic environment poses new challenges for the students in HEIs, as the compulsory use of technology and the Internet has inevitably transformed the learning process.

On one hand, to attend online classes students are required to learn the application of different electronic platforms with different and constantly improving features, to find electronic learning resources specified by their teachers or by their independent online searches using various electronic resources and to handle other new challenges of learning in a digital environment.

\footnotetext{
${ }^{1}$ Plovdiv University, Educational Faculty, Education and Management of Education, Bulgaria, dora.levterova@pfpu.bg

${ }^{2}$ Plovdiv University, Educational Faculty, Education and Management of Education, Bulgaria, galin.tsokov@pfpu.bg
} 
On the other hand, online learning requires greater independence, initiative and active participation in the learning process, dynamic and rapid changes in each student's learning style to match the new and rapidly changing requirements of learning in an electronic environment.

Due to these challenges, students in HEIs constantly require new cognitive, emotional, and social engagement to enhance their digital competencies. The forced and very dynamic transformation of Education 2.0 into Education 3.0, Education 4.0 and even into Education 5.0, highlighted the need to refine the self-efficacy of distance learning in an electronic environment. Modern models of distance education in an electronic environment has made it ubiquitous i.e. every student from HEIs can study at any time and at any place, availability of a good quality electronic device, good resolution of information transmission and good Internet connectivity are sufficient.

On a different note, for distance learning in an e-learning environment to be effective in HEIs, there is a significant role of personal constructs in regulating the behaviour of the students for their active and independent learning. As a basic construct in this context, self-efficacy can be noted in terms of learning or academic self-efficacy.

Self-efficacy is self-actualized through the self-verification of learners, including when realized as academic self-efficacy. Academic self-efficacy can be defined as personal beliefs to achieve specific goals and effectively solve certain tasks in an academic context (Bandura, 1997; Schunk \& Pajares, 2002; Veenman et al, 2006; Jansen et al, 2015; Džinović et al, 2018).

Academic self-efficacy influences the learning goals and academic achievements of students in HEIs . Self-efficacy affects motivation, learning, academic success and achievement (Bandura, 1977; Bandura, 1997; Schunk \& Pajares 2002; Bong et al, 2012; Talsma et al, 2018). Academic self-efficacy in an electronic environment is influenced by students' digital competence, their self-assessment of digital competence, past experiences, observations, physical indices, and verbal influences. (Bandura, 1997). The 4Cs (communication, cooperation, critical thinking, and creativity) are the key skills of the 21st century that influence the academic self-efficacy of students in HEIs.

\section{Methodology}

The study is based on the constructs of socio-cognitive learning theories (Bandura, 1986, 1997), selfefficacy theory (Bandura, 1997); expectancy-value theory (Eccles \& Wigfield, 2002), academic selfregulation theory (Zimmerman, 1995) to identify and interpret factors that influence the self-efficacy of students in HEIs in distance learning in an electronic environment.

For the purposes of the research, a survey toolkit was developed to measure the self-efficacy of students in HEIs during distance learning in an electronic environment.

The questionnaire was divided into four sections and included 35 items: 15 items to measure selfefficacy; 4 items for self-assessment of digital competence; 7 items for self-assessment of the impact of distance learning in an electronic environment of $4 \mathrm{C}$; 2 items for self-assessment of academic selfeffectiveness with cognitive results and 7 items for academic achievements.

The responses were measured on a 5-point Likert scale, 1 for - strongly disagree, 2 for disagree, 3 for neutral, 4 for agree and 5 for strongly agree. The questionnaire was distributed among 200 students in HEIs in Bulgaria but only 134 students have responded. An anonymous online survey was conducted using the goole form.

The survey was conducted from December 2020 - March 2021.

\section{Results and Discussion}

The collected data has been analysed methodologically and the results of the study are presented in the figures and table below.

Figure 1 shows the results related to the self-efficacy of the students from HEIs. The respondents distinguished between confidence, belief in their capabilities of self-acceptance and acceptance of their achievements. Most of the respondents have responded with "agree" and "strongly agree" to most of the statements. A high degree of self-efficacy and self-acceptance has been found among the students for their future academic achievements.

It is noteworthy that for the item "I have never lied," very few respondents have responded with "strongly agree" or "agree". This fact indicates a lack of social desirability and openness among respondents while submitting their responses. 


\begin{tabular}{|l|r|r|r|r|r||}
\hline Figure 1: Self-efficacy [\%] \\
\hline & Strongly Agree & Agree & Neutral & Disagree & Strongly Disagree \\
\hline I like myself & 61.19 & 32.09 & 5.97 & 0.74 & 0 \\
\hline I am confident in myself & 48.5 & 38.06 & 10.46 & 1.49 & 1.49 \\
\hline I believe in my capabilities & 64.2 & 28.35 & 5.22 & 1.49 & 0.74 \\
\hline I accept myself as I am & 67.17 & 26.12 & 5.97 & 0.74 & 0 \\
\hline I do not underestimate myself and my achievements & 48.5 & 35.82 & 10.46 & 3.73 & 1.49 \\
\hline I have a positive attitude towards myself & 67.16 & 26.12 & 3.73 & 0.74 & 0 \\
\hline The opinion of others about me is important to me & 25.37 & 24.62 & 20.89 & 17.99 & 11.13 \\
\hline I always reward myself for my academic success & 29.85 & 25.73 & 23.88 & 13.43 & 7.11 \\
\hline I set achievable goals & 59.7 & 27.62 & 11.94 & 2.98 & 0.74 \\
\hline My life has my rhythm and pace & 69.4 & 18.66 & 9.7 & 2.24 & 0 \\
\hline I know my strengths & 59.7 & 32.84 & 5.97 & 0 & 1.49 \\
\hline I know my weaknesses & 79.1 & 20.16 & 0.74 & 0 & 0 \\
\hline I am very critical of myself & 46.26 & 27.61 & 17.93 & 6.71 & 1.49 \\
\hline I have never lied & 2.98 & 4.48 & 11.19 & 61.95 & 19.4 \\
\hline I'm happy & 61.94 & 29.1 & 8.96 & 0 & 0 \\
\hline Source: Authors & \multicolumn{7}{|c|}{} & & & \\
\hline
\end{tabular}

\begin{tabular}{|l|c|c|c|c|c|}
\hline \multicolumn{2}{|l|}{ Table 1: Self-effectiveness Component [\%] } \\
\hline \multicolumn{1}{|c|}{ Legend 1. Column } & Strongly Agree & Agree & Neutral & Disagree & $\begin{array}{c}\text { Strongly } \\
\text { Disagree }\end{array}$ \\
\hline I am confident in myself & 48.50 & 38.06 & 10.46 & 1.49 & 1.49 \\
\hline I believe in my own abilities & 64.20 & 28.35 & 5.22 & 1.49 & 0.74 \\
\hline I accept myself as I am & 67.17 & 26.12 & 5.97 & 0.74 & 0 \\
\hline $\begin{array}{l}\text { I do not underestimate myself } \\
\text { and my achievements }\end{array}$ & 48.50 & 35.82 & 10.46 & 3.73 & 1.49 \\
\hline
\end{tabular}

\section{Source: Authors}

The results for digital self-efficacy are presented in Figure 2. In their daily functioning of life, and for online learning, to achieve their learning goals and perform tasks, the respondents have to use new and different functionalities of electronic platforms. At the heart of this need, respondents rated their digital competence including the use of the functionalities of e-learning platforms, and even the use of artificial intelligence components in training as average. The possible reasons for the average rating of digital self-efficacy are:

- Cautious self-assessment of digital competence due to constantly emerging new functionalities and use of more than one electronic learning platform;

- Neutral and even low psychological support for the development of more learning technologies in an electronic environment;

- Ambiguities and moral debates regarding artificial intelligence in daily life and learning;

- motivation for greater use of electronic technologies in the learning space and life;

- Covert or intertwined emotional reactions towards electronic technology;

- Careful self-assessment of digital competence in the vast world of electronic platforms, electronic resources and electronic learning models.

\begin{tabular}{|c|c|c|c|c|c|}
\hline \multicolumn{6}{|l|}{ Figure 2: Digital Self- efficiency [\%] } \\
\hline & Strongly Agree & Agree & Neutral & Strongly Disagree & Disagree \\
\hline $\begin{array}{l}\text { I know the functionalities of electronic learning } \\
\text { platforms }\end{array}$ & 56.72 & 37.32 & 5.22 & 0.74 & 0 \\
\hline $\begin{array}{l}\text { I know how to use the functionalities of electronic } \\
\text { learning platforms }\end{array}$ & 56.72 & 37.32 & 5.22 & 0.74 & 0 \\
\hline $\begin{array}{l}\text { In our training we use components of artificial } \\
\text { intelligence }\end{array}$ & 38.80 & 35.07 & 15.67 & 5.97 & 4.49 \\
\hline I have high digital competence & 39.58 & 30.60 & 26.86 & 2.96 & 0 \\
\hline Distance learning is boring & 14.92 & 8.20 & 26.86 & 10.44 & 39.58 \\
\hline $\begin{array}{l}\text { Distance learning motivates me more to learn than } \\
\text { face-to-face learning }\end{array}$ & 19.40 & 14.92 & 23.14 & 9.70 & 32.84 \\
\hline
\end{tabular}

Source: Authors

Undoubtedly, other reasons can also be sought. At the same time, the comparison with the results for knowledge and use of electronic platforms to be used in the process of their learning presents higher 
levels of digital competencies among respondents. This fact could definitely be related to the casualness of academic success and the academic achievements of the respondents.

Figure 2 presents some interesting results regarding the impact of distance learning in the eenvironment on the knowledge, skills and personal development of the respondents. A mixed response has been received regarding the influence of distance learning in an electronic environment on the 4Cs of the respondents.

A slightly higher advantage in terms of seeking additional information has been reported $(45.52 \%)$, but still half of the respondents do not agree with this statement. Probably, the respondents fail to recognise the effective application of $4 \mathrm{Cs}$ in the electronic environment. Obviously, to improve the level of educational achievements and personal self-improvement, the pedagogical agents, are still referring to the dimensions of the face-to-face education model. The self-assessment of the respondents is probably stereotyped as that of face-to-face learning experience and the self-referential information and resulted in the lower assessment of the academic goals and tasks.

Respondents' self-assessment of self-efficacy is quite high as $48.50 \%$ respondents strongly agree that they do not underestimate themselves and their achievements and $67.17 \%$ respondents strongly opined that they accept themselves as they are. Digital self-efficacy among respondents is relatively low, selfesteem in the self-acceptance of its individual components varies from $38.80 \%$ to $56.72 \%$.

\begin{tabular}{|c|c|c|c|c|c|}
\hline \multicolumn{6}{|l|}{ Figure 3: Distance Learning and $4 \mathrm{Cs}[\%]$} \\
\hline & $\begin{array}{l}\text { Strongly } \\
\text { Agree }\end{array}$ & Agree & Neutral & $\begin{array}{l}\text { Strongly } \\
\text { Disagree }\end{array}$ & Disagree \\
\hline Distance learning has increased my creativity & 38.06 & 25.37 & 21.64 & 10.48 & 5.97 \\
\hline $\begin{array}{l}\text { My communication skills improved during distance } \\
\text { learning }\end{array}$ & 32.84 & 21.64 & 17.91 & 18.65 & 7.64 \\
\hline Distance learning provokes my critical thinking & 28.35 & 28.86 & 24.62 & 10.48 & 9.70 \\
\hline $\begin{array}{l}\text { During distance learning I work more in a team with } \\
\text { my fellow students than during face-to-face training }\end{array}$ & 28.35 & 26.86 & 23.88 & 13.43 & 7.64 \\
\hline $\begin{array}{l}\text { In distance learning I master more knowledge than in } \\
\text { face-to-facetraining }\end{array}$ & 29.10 & 26.86 & 20.15 & 13.43 & 10.48 \\
\hline $\begin{array}{l}\text { I am always looking for additional information and } \\
\text { literature on the subjects I study }\end{array}$ & 45.52 & 29.85 & 15.67 & 5.97 & 5.97 \\
\hline $\begin{array}{l}\text { In distance learning I have to be more careful during } \\
\text { the learning process than in face-to-face learning }\end{array}$ & 31.34 & 16.46 & 31.34 & 14.92 & 5.97 \\
\hline
\end{tabular}

The referred interpretations are also visible in the comparison of the self-efficacy with the knowledge possessed by fellow students. A comparison of the self-efficacy of the students has been made through the prism of cognitive outcomes (Figure 4), the knowledge possessed is rated at a much higher level than the assessment of knowledge. The mechanism of cognitive distortion may have been triggered, this interpretation is in some contradiction with self-efficacy.

A better way to assess the efficacy of the students is through the prism of assessment by a significant other i.e. the teacher. Even for respondents with a very high assessment of self-efficacy, the level of mastery (the individual's experience of success in real life) is not unquestionably clear. Self-efficacy has to overcome the barriers of real achievements.

According to Pajares \& Schunk (2001), the direction of the causal relationship between self-efficacy and academic achievement (to which personal characteristics that determine the action of the four predictors of self-efficacy can be added) is described as "the most thorny problems" in this area.

It could be safely argued that in the comparative analysis of self-efficacy and the actual assessment of academic achievement, it is possible for a crisis of self-efficacy to occur or for the direction of selfefficacy to be adjusted. In the light of corrective models in self-efficacy, the discrepancies in the ratings of items like "accurately assess my knowledge and skills in the distance learning process" and "teachers underestimate my knowledge and skills" are quite logical. A similar discrepancy is observed with the commented items and the item "I am proud of my achievements". On one hand, the respondents reported three items that they have underestimated, on the other hand, they reported that are proud of their academic achievements. Of course, an optimistic reflection on these results can be made, related to the level of confidence in the possessed knowledge and skills. However, more objective interpretations can be drawn according to Phan (2012), in an academic environment, 
learners reflect on their performance and use this information while formulating their beliefs about self-efficacy, which then affect subsequent implementations.

\begin{tabular}{|l|l|r|r|r|r|r|}
\hline \multicolumn{2}{|l|}{ Figure 4: Self-efficacy and academic achievements [\%] } \\
\hline & $\begin{array}{l}\text { Strongly } \\
\text { Agree }\end{array}$ & \multicolumn{1}{l|}{ Agree } & Neutral & $\begin{array}{l}\text { Strongly } \\
\text { Disagree }\end{array}$ & Disagree \\
\hline Teachers underestimate my knowledge and skills & 47.00 & 18.66 & 13.43 & 11.21 & 9.70 \\
\hline $\begin{array}{l}\text { Our teachers do not provide enough e-learning } \\
\text { resources for learning }\end{array}$ & 43.28 & 16.40 & 14.18 & 12.68 & 13.0 \\
\hline $\begin{array}{l}\text { They accurately assess my knowledge and skills } \\
\text { in distance learning }\end{array}$ & 21.79 & 10.60 & 18.65 & 34.48 & 14.48 \\
\hline I have more knowledge than my fellow students & 43.98 & 34.18 & 15.80 & 3.72 & 2.32 \\
\hline $\begin{array}{l}\text { I have more knowledge and skills than my fellow } \\
\text { students, but lower grades }\end{array}$ & 50.0 & 23.14 & 10.44 & 9.70 & 6.72 \\
\hline I am proud of my academic achievements & 50.75 & 29.85 & 18.66 & 0.74 & 0 \\
\hline Source: Authors
\end{tabular}

Obviously, from the responses, it can be said that there is a cognitive load in the learning process related to mastering new competencies in an electronic environment, but also it is evident from the responses that there is an effect of cognitive distortion on self-efficacy and efficiency relationship. A cognitive distortion is evident from the item "I am proud of my academic achievements" and the other items on this scale. Cognitive load may be associated with the many interactive components of the electronic environment that increase the sensory load and require greater concentration and another level of understanding and mastery of educational content. Hence the cognitive distortion happens in terms of perception, understanding and mastering learning content through distance learning in an electronic environment. In this regard, there is a residual self-efficacy of face-to-face learning, which competes with self-efficacy in distance learning in an electronic environment. Although e-learning is a new model of learning, residual self-efficacy is not a new phenomenon.

According to Bandura \& Locke (2003) and Heggestad \& Kanfer (2005), residual self-efficacy from past performance and the relationship to efficacy can lead to statistical results from artefacts. The selfefficacy and efficacy dichotomy has long been the subject of scientific debate, but as Talsma et al. (2018) in their research have looked for different ways to study the issue of interconnectedness, as they themselves use two new ways of research (self-efficacy $\rightarrow$ efficiency versus productivity $\rightarrow$ selfefficacy). Obviously, one can look for the explanatory models for the perceived self-efficacy and the real learning achievements in this direction.

\section{Conclusion}

Academic self-efficacy faces new challenges in online learning. The purpose of this article was to identify and substantiate possible determinants of perceived self-efficacy for distance learning in an electronic environment among the students from HEIs and also to identify the factors influencing the same. It has been found that the perceived self-efficacy of the respondents during distance learning in the e-environment through self-assessment of $4 \mathrm{C}$ (critical thinking, communication, cooperation and creativity) demonstrates that the 4Cs are still considered to be more effectively realized in face-to-face learning than in distance learning in an electronic environment. The cognitive load is considered high, but there is also an effect of cognitive distortion on the relationship between self-efficacy and effectiveness while comparing the perceived self-effectiveness with the evaluation by others. The perceived self-efficacy collides with the results of one's own achievements. In this context, digital selfefficacy faces the barriers of distance learning, and its study gives a new direction for future research. Every research study on self-efficacy helps in decoding it from different perspectives and contributes in better understanding of the concept. Even the most perfect research on self-efficacy is based on certain indicators and characteristics and their interpretation is mainly related to accepting or rejecting certain hypotheses. The most significant contribution of a study on self-efficacy in academic context is to support the learning process's effectiveness and quality and also to estimate the self-efficacy and effectiveness in the learning of students from HEIs. Trajectories for future research on the relationship between self-efficacy and effectiveness of distance learning in e-environment, mainly on the relationship between sensory and cognitive load/cognitive distortion and self-efficacy, digital selfefficacy, learning, and academic self-efficacy are outlined. Distance learning in an e-learning environment sets increasingly challenging goals for the students in terms of the transition from the 
traditional learning model to the distance learning model and the competencies and self-effectiveness of stundents in HEIs for their learning.

\section{Acknowledgements}

The research was financed by Diversasia project 618615-EPP-1-2020-1-UK-EPPKA2-CBHE, funded by Erasmus+.

\section{References}

Bandura, A. (1986). Social foundations of thought and action: A social cognitive theory. Englewood Cliffs, NJ: PrenticeHall.

Bandura, A. (1977). Self-efficacy: Toward a unifying theory of behavioral change. Psychological Review, 84(2), 191215. https://doi.org/10.1037/0033-295X.84.2.191

Bandura, A. (1997). Self-Efficacy: The exercise of control. New York, NY: Worth Publishers.

Bandura, A., \& Locke, E. A. (2003). Negative self-efficacy and goal effects revisited. Journal of Applied Psychology, 88(1), 7-99. DOI: https://doi.org/10.1037/0021-9010.88.1.87

Bong, M., Cho,C., Ahn, H.S. \& Kim, H.J. (2012) Comparison of Self-Beliefs for Predicting Student Motivation and Achievement. The Journal of Educational Research, 105(5), 336-352. DOI: 10.1080/00220671.2011.627401

Eccles, J. S., \& Wigfield, A. (2002). Motivational beliefs, values, and goals. Annual Review of Psychology, 53,1, 109132. DOI: https://doi.org/10.1146/annurev.psych.53.100901.135153

Heggestad, E. D., \& Kanfer, R. (2005). The Predictive Validity of Self-Efficacy in Training Performance: Little More Than Past Performance. Journal of Experimental Psychology: Applied, 11(2), 84-97. DOI: https://doi.org/10.1037/1076898X.11.2.84

Jansen, W., Otten, S. \& van der Zee, C. (2015). Being part of diversity. The effects of an all-inclusive multicultural diversity approach on majority members' perceived inclusion and support for organizational diversity efforts.Group Process and Intergroup Relations, 1-16. DOI: https://doi.org/10.1177/1368430214566892 -

Pajares, F., \& Schunk, D. H. (2001). Self-beliefs and school success: Self-efficacy, self-concept, and and school achievement. In R. J. Riding \& S. G. Rayner (Eds.), Self perception (pp. 239-265). Ablex Publishing.

Phan, H. P. (2012). Informational sources, self-efficacy and achievement: A temporally displaced approach. Educational Psychology, 32(6), 699-726. https://doi.org/10.1080/01443410.2012.708320

Schunk, D. H., \& Pajares, F. (2002). The development of academic self-efficacy. In A. Wigfield \& J. S. Eccles (Eds.), Development of achievement motivation (pp. 15-31). Academic Press. https://doi.org/10.1016/B978-0127500539/50003-6

Siemens, G. (2005). Connectivism: A learning Theory for the digital age. International Journal of Instructional Technology and Distance Learning, 2 (1). Retieved from http://www.itdl.org/

Talsma, K., Schüz, B., Schwarzer, R., \& Norris, K. (2018). I believe, therefore I achieve (and vice versa): A meta-analytic cross-lagged panel analysis of self-efficacy and academic performance. Learning and Individual Differences, 61, 136150. DOI: https://doi.org/10.1016/j.lindif.2017.11.015

Veenman, M.V.J., Van Hout-Wolters, B.H.A.M. \& Afflerbach, P. (2006) Metacognition and learning: conceptual and methodological considerations. Metacognition Learning 1, 3-14. DOI: https://doi.org/10.1007/s11409-006-6893-0

Zimmerman, B. J. (1995). Self-efficacy and educational development. In A. Bandura (Ed.), Self-efficacy in changing societies (pp. 202-231). Cambridge University Press. https://doi.org/10.1017/CBO9780511527692.009 